\title{
KECAKAPAN MAHASISWA MEMANFAATKAN TEKNOLOGI INFORMASI DALAM LAYANAN BIMBINGAN DAN KONSELING
}

\author{
Ni Made Diah Padmi, Hendry Marthen \\ Universitas Borneo Tarakan \\ Email: diahpadmi@gmail.com
}

\begin{abstract}
Abstrak
Teknologi informasi sudah menjadi kebutuhan bagi semua kalangan dalam berbagai bidang baik dalam kehidupan sehari-hari maupun pekerjaan, kebutuhan akan teknologi informasi juga melekat pada bidang-bidang pendidikan termasuk bidang bimbingan dan konseling pun dewasa ini tidak lepas dari penerapan fasilitas teknologi informasi. Teknologi informasi merupakan sarana/alat yang digunakan untuk menyampaikan informasi atau sebagai media komunikasi. Dalam layanan bimbingan maupun konseling sangat erat kaitanya dengan penyampaian informasi maupun proses komunikasi, sehingga dalam eksistensinya bimbingan dan konseling sangat membutuhkan adanya teknologi yang mendukung pemberian layanan. Banyaknya fasilitas teknologi informasi yang dapat digunakan berdampak pada keharusan bagi praktisi bimbingan dan konseling untuk mampu memanfaatkannya, maka keterampilan dalam mengaplikasikan teknologi-teknologi tersebut harus senantiasa ditingkatkan. Penelitian ini tertarik untuk mengetahui kecakapan/keterampilan mahasiswa dalam memanfaatkan teknologi informasi yang mampu mendukung kegiatan bimbingan dan konseling, sehingga dalam penelitian ini bertujuan untuk mendeskripsikan kecakapan mahasiswa memanfaatkan teknologi informasi dalam layanan bimbingan dan konseling. Metode penelitian yang digunakan adalah kualitatif deskriptif dengan menggunakan angket online sebagai instrument utama dalam pengumpulan data. Hasil yang diperoleh berdasarkan analisis angket online skor rata-rata 69 dengan kategori tinggi, sedang dan rendah. Persentase dari keseluruhan subjek menunjukkan $51 \%$ memiliki skor dibawah rata-rata $\leq 69$.
\end{abstract}

Kata Kunci : Teknologi informasi, bimbingan dan konseling

\section{PENDAHULUAN}

Teknologi informasi saat ini menjadi kebutuhan utama dalam berbagai bidang, dan tidak melupakan juga bidang pendidikan yang sepanjang tahun 2020 ini menjadi sangat membutuhkan keberadaan teknologi dan informasi berbasis internet (online system). Dalam situasi pandemic seperti ini, alam kita manusia dipaksa untuk memberi jarak satu sama lain dengan tidak sering bertatap muka maupun berinteraksi langsung, sehingga diperlukan teknologi komunikasi jarak jauh yang dapat membuat komunikasi berlangsung tanpa memandang ruang 
dan waktu dan bisa berlangsung aman dan cepat.

Upaya-upaya yang sedang dilakukan oleh tenaga-tenaga pendidik adalah dengan mulai menerapkan pembelajaran berbasis multimedia, $e$ learning, blanded learning dan juga pemanfaatan beberapa aplikasi komputer dalam kegiatan belajar dan mengajar. Selain upaya dari tenaga pendidik, tokoh-tokoh pemerhati perkembangan teknologi juga semakin marak menciptakan situs-situs internet maupun aplikasi melalui smartphone yang menyediakan berbagai materi pelajaran yang dapat diakses secara gratis maupun berbayar yang tujuannya tidak lain adalah untuk menunjang ketercapaian target kompetensi dasar yang harus dikuasai oleh peserta didik.

Bimbingan dan konseling yang merupakan bagian integral pendidikan juga tidak luput dari sentuhan-sentuhan perkembangan teknologi. Ditegaskan peranan bimbingan dan konseling dalam system pendidikan nasional melalui UU No. 20 tahun 2003 tentang system pendidikan nasional serta penegasan profesi bimbingan dan konseling dalam tatanan pedidikan formal (ABKIN, 2008) seharusnya menjadi rujukan utama para guru BK (konselor) dalam mengoptimalkan fungsi teknologi dalam setiap layanan yang diberikan, baik secara klasikal, kelompok maupun dengan format individual.

Semakin maju dan berkembangnya zaman, seluruh aspek kehidupan pun menyesuaikan dengan kemajuan tersebut agar tidak out of date atau ketinggalan dalam mengikuti perkembangan zaman (Kusmanto, 2015).
Informasi yang semakin canggih dan juga sangat berperan dalam mempermudah kinerja SDM, akan menjadi suatu daya tarik yang kuat untuk mengaplikasikannya dalam wilayah pendidikan. Oleh karena itu, penerapan teknologi informasi dalam aspek pendidikan akan menjadi suatu urgensi tersendiri dalam mengimbangi kemajuan zaman yang semakin mutakhir.

Teknologi informasi memiliki beberapa fungsi dan peran dalam mengoptimalisasi layanan bimbingan dan konseling (Triyanto, 2010), yaitu:

a. Publikasi: Teknologi Informasi dimanfaatkan sebagai sarana pengenalan kepada masyarakat luas dan juga sebagai pemberi informasi mengenai layanan Bimbingan dan Konseling.

b. Pelayanan dan Bantuan: bimbingan dan konseling dilakukan secara tidak langsung dengan bantuan teknologi informasi. Sehingga layanan BK dapat tetap diberikan meskipun tanpa tatap muka.

c. Pendidikan: di dalam informasi yang diberikan melalui sarana Teknologi Informasi mengandung unsur pedidikan.

Namun permasalahannya, dari hasil pengamatan tercatat beberapa fakta yang berkaitan dengan keterampilan penggunaan teknologi komputer, informasi dan komunikasi yang dimiliki oleh guru BK dan calon guru BK dalam proses layanan bimbingan dan konseling seperti berikut ini:

Hasil observasi terhadap guru BK di salah satu sekolah di Tarakan yang menunjukkan bahwa pelaksanaan 
impunan data dan aplikasi instrument masih menggunakan cara manual dibandingkan dengan memanfaatkan teknologi komputer berbasis internet (google formulir/cloud storage/survey monkey/typeform/zoho survey)

Hasil observasi terhadap guru BK di salah satu sekolah di Tarakan yang menunjukkan bahwa penyimpanan data siswa masih menggunakan manual buku atau aplikasi komputer seadanya saja.

1. Hasil observasi terhadap calon guru BK/mahasiswa pada mata kuliah Teknologi Informasi dalam BK di Universitas Borneo Tarakan yang menunjukkan bahwa minimnya keterampilan mahasiswa dalam menyusun media layanan BK. Minimnya keterampilan tersebut bukan hanya karena kurangnya kesadaran mahasiswa dalam berinovasi namun juga karena kurangnya pengetahuan mahasiswa terkait media-media layanan $\mathrm{BK}$ berbasis komputer, teknologi informasi dan teknologi komunikasi dan cara menyusunnya.

2. Belum adanya penggunaan fasilitas media sosial (facebook, instragram, twiter, WA) yang digunakan sebagai media sosialisasi layanan BK untuk menegaskan kiprah bimbingan dan konseling di sekolah, sehingga meminimalisir kesalahpahaman peserta didik maupun khalayak umum terkait BK di Sekolah.

Memperhatikan fakta-fakta hasil observasi tersebut, menunjukkan sebaliknya dari harapan besar tentang produktifitas kinerja SDM berbantuan teknologi informasi dan komunikasi. Khususnya produktifitas kinerja guru BK. Oleh karena itu, perlu diketahui bagaimana pemanfaatan teknologi informasi, khususnya bagi calon guru BK (mahasiswa bimbingan konseling) yang merupakan generasi baru BK masa kini.

Sehingga berdasarkan berbagai permasalahan yang mampu diamati, pada penelitian ini dirumuskan permasalahan seberapa jauh pemanfaatan teknologi informasi dalam layanan bimbingan dan konseling? Sehingga tujuan dari penelitian ini adakah mendeskripsikan seberapa jauh pemanfaatan teknologi informasi dalam layanan bimbingan dan konseling

\section{METODE PENELITIAN}

Penelitian ini menggunakan metode kualitatif deskriptif yang bertujuan untuk mendeskripsikan kecakapan mahasiswa memanfaatkan teknologi informasi dalam layanan bimbingan dan konseling. Penelitian ini memilih subjek penelitian yaitu mahasiswa BK di lingkungan Universitas Borneo Tarakan yang telah lulus atau yang sedang mengikuti Mata Kuliah Teknologi Informasi dalam BK yaitu sebanyak 70 mahasiswa. Instrument utama yang digunakan adalah angket yang disebarkan secara online dan di disain dengan bantuan google formulir dan disebar melalui Whatsapp Group sebagai media komunikasi utama antara peneliti dengan subjek penelitian, metode pengumpulan data pendukung dilakukan dengan teknik wawancara dan observasi. Penelitian dilaksanakan mulai awal bulan juni hingga oktober 2020. Adapun alur penelitian ini digambarkan sebagai berikut:

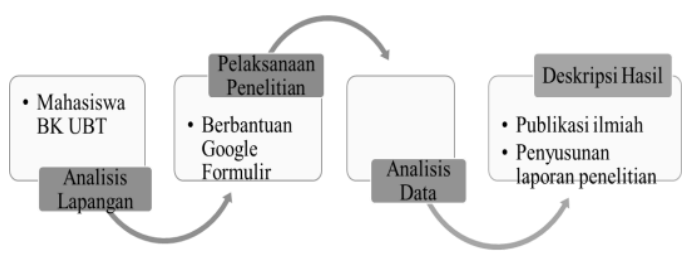


Gambar 1. Road Map Penelitian

\section{HASIL DAN PEMBAHASAN}

Secara garis besar, dalam penelitian ini menilai empat aspek yang cukup kuat kaitanya dengan kecakapan memanfaatkan TIK, yaitu:

a. Pengalaman dalam menggunakan TIK

b. Kemampuan dalam mengakses informasi

c. Pemanfaatan berbagai aplikasi internet

d. Keterampilan dalam memanfaatkan aplikasi internet

Berdasarkan data-data yang diperoleh selama penelitian baik data analisis angket maupun hasil observasi dan wawancara, diperoleh distribusi data sebagai berikut:

\section{Tabel 1. Data Hasil Penelitian}

\begin{tabular}{|c|c|c|c|c|}
\hline Hasil & $\begin{array}{c}\text { Fre } \\
\text { k }\end{array}$ & \% & $\begin{array}{c}\text { Rata } \\
- \\
\text { Rata }\end{array}$ & $\begin{array}{c}\text { Persentas } \\
\text { e }\end{array}$ \\
\cline { 1 - 2 } $\begin{array}{c}\text { Sangat } \\
\text { Tinggi }\end{array}$ & - & - & & \multirow{2}{*}{$\begin{array}{c}51 \% \text { di } \\
\text { bawah } \\
\text { rata-rata }\end{array}$} \\
\cline { 1 - 2 } Tinggi & 10 & $\begin{array}{c}14 \\
\%\end{array}$ & 69 & \\
\cline { 1 - 2 } Sedang & 42 & $\begin{array}{c}60 \\
\%\end{array}$ & & \\
\cline { 1 - 2 } $\begin{array}{c}\text { Renda } \\
\text { h }\end{array}$ & 18 & $\begin{array}{c}26 \\
\%\end{array}$ & & \\
\cline { 1 - 2 } $\begin{array}{c}\text { Sangat } \\
\text { Renda } \\
\text { h }\end{array}$ & - & - & & \\
\hline
\end{tabular}

Data yang digambarkan dalam Tabel 1, menunjukkan $51 \%$ mahasiswa yang memiliki skor di bawah rata-rata, dengan kata lain terdapat sebagian besar mahasiswa yang masih belum memiliki kecakapan yang cukup dalam memanfaatkan TIK khususnya pada penerapan layanan BK. Dari $51 \%$ mahasiswa dengan skor dibawah ratarata terdapat 18 mahasiswa yang termasuk pada kategori rendah, sehingga hal ini juga menjadi bahan tindak lanjut bagi dosen pengampu mata kuliah untuk meningkatkan keterampilan mahasiswa dalam mengaplikasikan TIK dalam perannya sebagai sarana pendukung layanan BK.

(Setiawan, 2016) Konselor harus pintar-pintar dalam memanfaatkan teknologi dan informasi, penguasan teknologi informasi bagi konselor merupakan nilai tambah dalam memberikan pelayanan bimbingan dan konseling. Sehingga layanan bimbingan dan konseling dapat dilaksanakan sesuai dengan kebutuhan masyarakat dan tentunya mendasar pada asas kebutuhan dan kekinian.

Kecakapan dalam memanfaatkan teknologi informasi tidak hanya penting bagi konselor saja, tetapi mahasiswa BK yang merupakan generasi emas BK masa depan juga perlu menguasai teknologi informasi khususnya yang mampu mendukung pemberian layanan baik bimbingan maupun konseling.

Berdasarkan analisis data yang telah dilakukan serta mengacu pada data hasil penelitian pada Tabel 1, dapat digambarkan hasil dari empat aspek yang dinilai, sebagai berikut: 


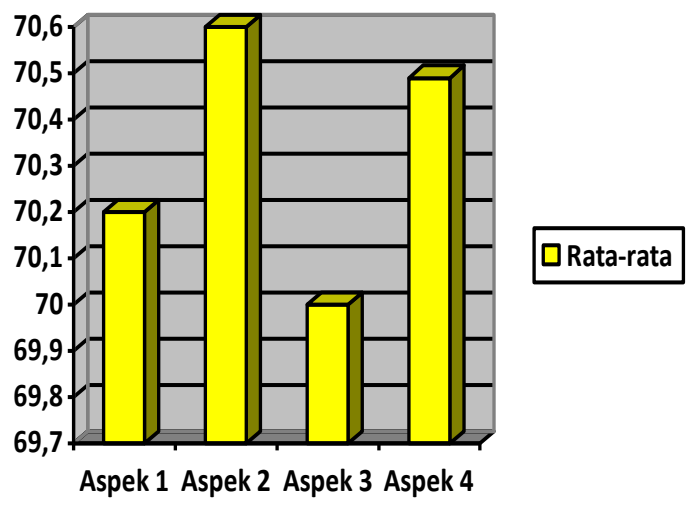

\section{Gambar 2. Grafik Analisis Data Penelitian}

Mengacu pada analisis data penelitian yang digambarkan pada Gambar 2 tersebut, dapat dilihat perbandingan skor rata-rata pada masing-masing aspek yang dinilai. Aspek dengan skor rata-rata tertinggi adalah kemampuan mahasiswa dalam mengakses informasi sedangkan aspek dengan skor rata-rata paling rendah adalah pemanfaatan berbagai aplikasi internet.

(Pautina, 2017) Dalam era informasi dewasa ini, kecanggihan teknologi informasi dan komunikasi telah memungkinkan terjadinya pertukaran informasi yang cepat tanpa terhambat oleh ruang dan waktu. Dengan kata lain sebagai layanan yang tidak lepas dari proses komunikasi maka layanan bimbingan dan konseling terkhusus jika dikaitkan dengan kondisi pandemic yang melanda dunia sepanjang tahun 2020, maka sangat dibutuhkan adanya media yang dapat digunakan sebagai alat penyampaian informasi maupun alat komunikasi, yang memungkinkan layanan BK tetap eksis meskipun tanpa dilakukanya tatap muka.
Awal terbentuknya bimbingan konseling masih diartikan sebagai hubungan/interaksi tatap muka antara konselor dengan konseli, dan seiring berjalannya waktu, dengan kemudahan dari Teknologi Informasi, pemberian layanan baik bimbingan maupun konseling dapat dilaksanakan dengan metode jarak jauh maupun tatap muka langsung. Hal tersebut yang tentunya merubah konsep bimbingan dan konseling.

(Setiawan, 2016) Layanan Bimbingan dan Konseling yang sifatnya inovatif sudah tentunya dapat membangkitkan dan meningkatkan nilai tambah bagi pelayanan BK serta tujuan layanan dapat tercapai dengan baik.

Untuk mewujudkan kecakapan dalam mengaplikasikan teknologi informasi diperlukan adanya kemauan untuk belajar pada setiap individu dalam hal ini yaitu mahasiswa maupun praktisi BK di sekolah dan lingkup umum. Kecakapan memanfaatkan teknologi informasi tidak hanya sekedar mengenal fasilitas-fasilitas teknologi informasi apa saja yang tersedia, tetapi lebih kepada kemampuan dalam menggunakannya, mengaplikasikan fasilitas tersebut untuk membantu kegiatan/aktifitas layanan BK.

Dalam penelitian ini, beberapa hal yang diperoleh adalah mahasiswa BK masih didonominasi dengan kurang cakap dalam memanfaatkan teknologi informasi, terdapat mahasiswa yang hanya sekedar mengetahui saja aplikasi tersebut tetapi tidak terlalu familiar dalam penggunaanya. Sehingga penelitian ini dapat dijadikan sebagai bahan tindak lanjut dalam memberikan mata kuliah khususnya mata kuliah yang berkaitan langsung dengan 
Teknologi dan informasi dalam BK maupun Mata Kuliah Media-Media dalam Layanan BK, sehingga dapat menjadi bahan persiapan bagi mahasiswa sebelum terjun ke lapangan.

\section{KESIMPULAN}

Berdasarkan hasil penelitian, diperoleh simpulan sebagai berikut:

\section{Kecakapan} mahasiswa memanfaatkan teknologi informasi diperoleh persentase sebanyak $51 \%$ mahasiswa memiliki skor di bawah rata-rata, yaitu $\leq 69$.

2. Berdasarkan aspek-aspek yang diukur, skor paling tinggi ditunjukkan pada aspek kemampuan mahasiswa dalam mengakses informasi, sedangkan skor paling rendah ditunjukkan pada keterampilan mahasiswa memanfaatkan berbagai aplikasi dari internet.

3. Masing-masing aspek yang diukur menunjukkan bahwa masih banyak mahasiswa yang belum cakap dalam mengaplikasikan teknologi informasi. Bahwa kecakapan dalam mengaplikasikan internet sangat dibutuhkan dan erat kaitanya dalam pemberian layanan BK yang merupakan proses penyampaian informasi dan tidak lepas dari proses komunikasi.

\section{REFERENSI}

ABKIN. 2008. Penegasan Profesi Bimbingan dan Konseling Alur Pikir Penataan Pendidikan Profesional Konselor dan Layanan Bimbingan dan Konseling dalam Jalur Pendidikan Formal. Bandung: Abkin.
Kusmanto. 2015. Penggunaan Media dan Teknologi dalam Membentuk Karakter Cerdas Melalui Pelayanan Bimbingan dan Konseling. Prosiding Seminar Nasional Kebangkitan Teknologi

Pautina, A. R. (2017). Konsep Teknologi Informasi dalam Bimbingan dan Konseling. TADBIR: Jurnal Manajemen Pendidikan Islam, 1.

Setiawan, A. (2016). Peranan Teknologi Informasi dalam Bimbingan dan Konseling. Bitnet Jurnal Pendidikan Teknologi Informasi, 46.

Triyanto, Agus. 2010. Implikasi Perkembangan Teknologi Komputer dan Internet bagi Konselor Sekolah. Jurnal Paradigma. No.09. Th.V, Januari 